\title{
The Evaluation of RS1805086 and RS1805065 Polymorphisms in Mstn Gene and Anthropometric Properties of National and Amateur Arm Wrestlers
}

\author{
Evaluación de los Polimorfismos RS1805086 y RS1805065 en el Gen Mstn y las \\ Propiedades Antropométricas de los Luchadores de Brazo Nacionales y Amateurs
}

\author{
Gamze Usaç $^{1}$; Onur Eroglu ${ }^{1,2}$ \& Raif Zileli ${ }^{1,3}$
}

USAÇ, G.; EROGLU, O. \& ZILELI, R. The evaluation of rs1805086 and rs 1805065 polymorphisms in mstn gene and anthropometric properties of national and amateur arm wrestlers. Int. J. Morphol., 38(4):1148-1154, 2020.

SUMMARY: The aim of this study is to investigate rs1805086 and rs 1805065 polymorphisms of MSTN gene of national and amateur Turkish arm wrestlers and people leading a sedentary lifestyle, and the anthropometric properties such as hand, wrist, and forearm circumferences of national and amateur Turkish arm wrestlers are aimed to be explored. In this study, a total of 79 volunteers who were 24 national (7 females, 17 males) Turkish arm wrestlers, 21 amateur ( 7 females, 14 males) Turkish arm wrestlers and 34 sedentary people (12 females, 22 males) participated. To analyse the data, Statistical Package for the Social Sciences, SPSS 22 (SPSS Inc., Chicago, IL, USA) was used. As a result of the study, when data on rs1805086 and rs1805065 polymorphisms of MSTN gene were examined respectively, it was found out that MSTN 153KK genotype was $100.0 \%$ dominant in both national $(\mathrm{n}=24)$ and amateur $(\mathrm{n}=21)$ arm wrestlers, and it was $94.12 \%$ dominant in sedentary people. KR genotype was observed in $5.88 \%$ of the sedentary people. The data from the other rs 1805065 polymorphism of MSTN gene showed that all participants $(n=45,100.0 \%)$ were carriers of normal homozygous genotype. Furthermore, for both female group and male group, there found to be statistically significant difference in terms of anthropometric properties. It can be concluded that though there was no significant difference between national and amateur Turkish arm wrestlers in terms of their MSTN gene characteristics; in terms of anthropometric properties, significant differences were discovered. It was found out that on these athletes, not MSTN gene polymorphisms but anthropometric properties were effective.

KEY WORDS: Myostatin gene; Arm wrestling; Polymorphism; Athletic performance; Wrist circumference; Hand circumference; Forearm circumference.

\section{INTRODUCTION}

The changes in human elite athletic performance are determined by a complex interaction of sociocultural, psychological, and physiological factors (Brutsaert \& Parra, 2006). Athletes should be mindful not only of their food intake before a workout but also of their diet, and they should try to be away from depression and sudden changes in mood (Ulucan et al., 2013). All these factors are considered to be as the main factors contributing the athletic performance. Besides these factors, it is widely believed that the genetics is also one of the factors affecting the success of elite athletes. For many years, it has been known that athletic performance can be improved with the help of intense workout programs (Lortie et al., 1982). However, it is also known that some individuals have an innate athletic ability. The average performance of individuals with this innate ability is perfect before or after a workout. However, athletic ability is shaped by many physiological interactions which are affected by various factors (Brown, 2000).

Sports genomics is thought to be a scientific discipline focusing on genome organizations and their functioning on elite athletes. Genetic ability plays a crucial role in the improvement of physical athletic performance. Furthermore, it is associated with many gene polymorphisms (Macarthur \& North, 2005). As it is significant to define genetic variants that contribute to athletic performance, how polymorphisms in question and metabolic pathways affect the individual performance is one of the trendy research subjects in the field of

\footnotetext{
${ }^{1}$ Biotechnology Research and Application Center, Bilecik Seyh Edebali University, Bilecik, Turkey.

${ }^{2}$ Department of Molecular Biology and Genetics, Faculty of Science and Letters, Bilecik Seyh Edebali University, Bilecik, Turkey.

${ }^{3}$ School of Health, Bilecik Seyh Edebali University, Bilecik, Turkey.
} 
sports genetics (Ulucan et al.). Since the early 2000s, genes that affect human performance have been increasing in number each year. There thought to be approximately 250 genes affecting human performance. It is possible to analyse hundreds of SNPs in one try with molecular highly-productive techniques recently introduced to molecular genetics. Genomewide association studies (GWAS) have much valuable information on the impact of these SNPs in sports science. Studies in this field are becoming more common thanks to the information gained from the previous studies (Ulucan, 2015).

Polymorphisms of MSTN gene are also associated with athletic performance. Myostatin, is a defined member of transforming growth factor $\mathrm{b}$ (TGF- $\mathrm{b}$ ) family which is one of the regulating factors in the body. The myostatin (MSTN) gene is mostly expressed only in skeletal muscle cells of our body. It has been found out to be a negative regulator in muscle growth (McPherron et al., 1997; Amthor et al., 2002). Overexpression of the MSTN gene has been associated with reduced muscle mass (McPherron \& Lee, 1997; Grobet et al., 1997; Mosher et al., 2007). Furthermore, gene knockout (KO) (Schuelke et al., 2004) and inhibition of the gene signal (Li et al., 2008) lead to sudden muscle hypertrophy and /or hyperplasia. The MSTN gene is located at 2q32.2 (GeneCards - The Human Gene Database, 2018). MSTN homozygous mutation causes gene inactivation (Schuelke et al.). It is observed that this activation causes an over-increase in the muscle mass of particularly infants aged from 1 to 4,5. Furthermore, this also causes a deletion in the C-terminal region of the MSTN gene in the protein folding point. It has been reported that this deletion causes catalytic death and an increase in muscle mass (McPherron \& Lee; Girgenrath et al., 2005). In light of this information, it has been stated that deletion is an extra advantage for people who have inactive MSTN gene, and also elite athletes who do sports that require strength (Eroglu \& Zileli, 2015).

It is assumed that muscle hypertrophy in response to strength training can be modulated by exonic and nonsynonymous polymorphisms of MSTN gene. One of these polymorphisms is the rs 1805065 polymorphism located in exon 1 of the MSTN gene. The codon encoding the protein 55. amino acid contains a G-A change. This results in an alanine to threonine (A-T) substitution at position 55 of the amino acid. Therefore, this polymorphism is also known as the A55T polymorphism. Another polymorphism is rs1805086 polymorphism. The polymorphism rs 1805086 located in exon 2 of the genes withthree exons requires a change from $A$ to $G$ in the codon encoding the 153rd amino acid of myostatin. This polymorphism leads to the displacement of arginine (R) with the lysine $(\mathrm{K})$ protein at position 153; therefore, this is called the MSTN K153R polymorphism (Ferrell et al., 1999).
Many studies have been carried out on the genetic zones which are thought to be affecting the performances of athletes of various sports fields such as football, basketball, judo, and wrestling. However, studies done with Turkish athletes on this subject are not much fewer when it is compared with the studies in all literature (Ulucan et al.; Ulucan, 2015, 2016). Up until today, the studies on polymorphisms of MSTN gene have been carried out with athletes of other fields such as swimmers, athletes, bodybuilders and weightlifters. As the studies on literature do not cover a research on arm wrestling, in this study, it was aimed to investigate rs1805086 and rs 1805065 polymorphisms of national, amateur Turkish arm wrestlers and sedentary people, and the anthropometric properties such as hand, wrist, and forearm circumferences of these participants.

\section{MATERIAL AND METHOD}

Subject: In this study, a total of 79 volunteers who were 24 national (7 females, 17 males) Turkish arm wrestlers, 21 amateur ( 7 females, 14 males) Turkish arm wrestlers and 34 sedentary people (12 females, 22 males) participated. All the participants signed the voluntary consent forms, and all of them were informed about their results during and after the study, via their contact information they provided.

This study was approved by Eskisehir Osmangazi University Medical Faculty, Clinical Research Ethical Committee (2017/17). Moreover, the study was conducted in accordance with the requirements of the Declaration of Helsinki of the World Medical Association. This study, also, was supported by Bilecik Seyh Edebali University Scientific Research Projects (2017-01.BSEÜ.20-01).

DNA Isolation and Genotyping. The commercial kit (MACHEREY-NAGEL NucleoSpin® Blood) was used in the process of DNA isolation. The isolated DNAs, the purity of which was 1.60-1.90 ng / $\mathrm{ml}$ with A260 / A280 ratio and those with a concentration of 50-100 ng were included in the study.

MSTN rs1805086 Genotyping. The rs1805086 polymorphism of MSTN gene was determined by polymerase chain reaction-restriction fragment length polymorphism (PCR-RFLP) using the forward 5'GAAAACCCAAATGTTGCTTC-3' and reverse 5'TGTCTAGCTTATGAGCTTAGGG-3' primers. The PCR reactions were performed in a total volume of $50 \mathrm{~mL}$ containing $50 \mathrm{mM} \mathrm{KCl}, 1 \mathrm{mM}$ dNTP, $1.5 \mathrm{mM} \mathrm{MgCl} 2,10$ $\mathrm{mM}$ Tris- $\mathrm{HCl}(\mathrm{pH} 8.0), 1 \mathrm{mM}$ primers, $1.5 \mathrm{U}$ Taq DNA polymerase enzyme and 50-100 ng genomic DNA. Polymerase chain reaction was performed respectively with an initial denaturation at $96^{\circ} \mathrm{C}$ for 10 minutes followed by 
denaturation at $94{ }^{\circ} \mathrm{C}$ for a minute repeated 35 times, bonding at $53.8^{\circ} \mathrm{C}$ for a minute, extension at $72{ }^{\circ} \mathrm{C}$ for 30 seconds and a final extension at $72{ }^{\circ} \mathrm{C}$ for 7 minutes.

Genotyping of amplicons was maintained by restriction fragment length polymorphism technique. To identify the genotypes, BanII (New England Biolabs) restriction enzyme was used. Ethidium bromide-stained 3 $\%$ agarose gel electrophoresis was used to analyse fragments under UV light.

MSTN rs1805065 Genotyping. The rs 1805065 polymorphism of MSTN gene was determined by polymerase chain restriction fragment length polymorphism (PCR-RFLP) using forward 5'-CCTGTTTATGCTGATTGTTG-3' and reverse 5'-TACTGAGGATTTGTACTTAATAG-3' primers. The PCR reactions were performed in a total volume of 50 $\mathrm{mL}$ containing $50 \mathrm{mM} \mathrm{KCl}, 1 \mathrm{mM}$ dNTP, $1.5 \mathrm{mM} \mathrm{MgCl}$, $10 \mathrm{mM}$ Tris- $\mathrm{HCl}$ (pH 8.0), $1 \mathrm{mM}$ primers, $1.5 \mathrm{U}$ Taq DNA polymerase enzyme and 50-100 ng genomic DNA. Polymerase chain reaction was performed respectively with an initial denaturation at $96{ }^{\circ} \mathrm{C}$ for 10 minutes followed by denaturation at $94^{\circ} \mathrm{C}$ for a minute repeated 35 times, binding at $46.9{ }^{\circ} \mathrm{C}$ for a minute, extension at $72{ }^{\circ} \mathrm{C}$ for 30 seconds, and a final extension at $72{ }^{\circ} \mathrm{C}$ for 7 minutes. Genotyping of amplicons was maintained by restriction fragment length polymorphism technique.

To identify the genotypes, AluI (New England Biolabs) restriction enzyme was used. Ethidium bromidestained $3 \%$ agarose gel electrophoresis was used to analyze fragments under UV light.

Anthropometric Measurements. The forearm circumference was measured with a tape measure $12 \mathrm{~cm}$ below the olecranon while it was suspended with the elbow joint at $90^{\circ}$ of flexion (Anakwe et al., 2007). Radius and ulna were measured from the distal end for wrist circumference. The circumference of the hand was measured from the mid-point of hand's middle second and fifth metacarpal bones (Li et al., 2010). All measurements were taken by anthropometric tape meter (Gulick Meter) with a precision of $1 \mathrm{~mm} \pm$, and they were recorded in $\mathrm{cm}$. The anthropometric measurements of sedentary people were not included in this section since the athletes did not want to be measured before the training and as the exercises might affect the circumference measurements.

Statistical Analysis. To analyse the data, Statistical Package for the Social Sciences, SPSS 22 (SPSS Inc., Chicago, IL, USA) was used. The genotype distribution of MSTN gene between the groups and $\mathrm{K}, \mathrm{R}, \mathrm{A}, \mathrm{T}$ allele frequency were included in percentages. Normality of the data was evaluated by Shapiro Wilk test, and homogeneity of variance of the data was found by Levene test. To analyse the differences between the groups in terms of hand, wrist, and forearm circumference measurements, Independent Sample T Test was used, and the significance value was found out to be $\mathrm{p}<.05$.

\section{RESULTS}

The study group consisted of 24 national ( 7 females, 17 males) Turkish arm wrestlers, 21 amateur (7 females, 14 males) Turkish arm wrestlers and 34 sedentary (12 females, 22 males) participants. The genetic and anthropometric results of the study group are presented below:

The results from the data obtained showed that the dominant genotype in the rs 1805086 polymorphism of MSTN gene was KK. It can be seen that KK genotype is found $100 \%$ of the national and amateur athletes. While in sedentary participants KK genotype was found to be 94.12 $\%$ and KR genotype was $5.88 \%$, the RR genotype was not detected in any sedentary participants. There were no KR and RR genotypes found in national and amateur Turkish arm wrestlers (Table I).

Another finding investigated in our study was the rs1805065 polymorphism of MSTN gene. In this study, the dominant genotype of MSTN rs1805065 was identified as AA in the two of the groups studied on. It can be seen that AA genotype is found $100 \%$ of the national and amateur arm wrestlers and sedentary participants. There were no AT genotypes and TT genotypes found in all three groups (Table II).

According to the results of our study, while there was a statistically significant difference between national and amateur female arm wrestlers in terms of their hand circumference $(p<0.05)$, no statistically significant difference was found between the male athletes (Table III).

According to results of our study, there was also a statistically significant difference between female athletes in terms of wrist circumference ( $p<0.05)$. However, no statistically significant difference was found between male athletes in terms of this parameter (Table IV).

Another anthropometric feature we examined in our study is forearm circumference. When this parameter was evaluated, a statistically significant difference was found between both national and amateur female arm wrestlers and male national and amateur male arm wrestlers $(\mathrm{p}<0.05)$ (Table V). 
USAÇ, G.; EROGLU, O. \& ZILELI, R. The evaluation of rs1805086 and rs1805065 polymorphisms in mstn gene and anthropometric properties of national and amateur arm wrestlers Int. J. Morphol., 38(4):1148-1154, 2020.

Table I. The results on rs1805086 (K/R) polymorphism of MSTN gene in national arm wrestlers, amateur arm wrestlers, and sedentary participants.

\begin{tabular}{ccccc}
\hline MSTN rs1805086 & National Arm & Amateur Arm Wrestlers & Sedentary people Participants & Total \\
\hline KK & $24(100.0 \%)$ & $21(100.0 \%)$ & $32(94.12 \%)$ & $77(97.5 \%)$ \\
KR & $0(0.0 \%)$ & $0(0.0 \%)$ & $2(5.88 \%)$ & $2(2.5 \%)$ \\
RR & $0(0.0 \%)$ & $0(0.0 \%)$ & $0(0.0 \%)$ & $0(0.0 \%)$ \\
\hline
\end{tabular}

Table II. The results on rs1805065 (A/T) polymorphism of MSTN gene in national arm wrestlers, amateur arm wrestlers, and sedentary participants.

\begin{tabular}{ccccc}
\hline MSTN rs1805065 (A/T) & $\begin{array}{c}\text { National Arm } \\
\text { Wrestlers }(\mathrm{n}=24)\end{array}$ & $\begin{array}{c}\text { Amate ur Arm Wrestlers } \\
(\mathrm{n}=21)\end{array}$ & $\begin{array}{c}\text { Sedentary People } \\
\text { Participants }(\mathrm{n}=34)\end{array}$ & Total \\
\hline AA & $24(100.0 \%)$ & $21(100.0 \%)$ & $34(100.0 \%)$ & $79(100.0 \%)$ \\
AT & $0(0.0 \%)$ & $0(0.0 \%)$ & $0(0.0 \%)$ & $0(0.0 \%)$ \\
TT & $0(0.0 \%)$ & $0(0.0 \%)$ & $0(0.0 \%)$ & $0(0.0 \%)$ \\
\hline
\end{tabular}

Table III. Female/Male national and amatenur arm wrestlers' hand circumference.

\begin{tabular}{lccrr} 
& National Arm Wrestlers & Amateur Arm Wrestlers & $\mathrm{t}$ & $\mathrm{p}$ \\
& $\overline{\mathrm{x}} \pm \mathrm{sd}$ & $\overline{\mathrm{x}} \pm \mathrm{sd}$ & & \\
\hline Female & $20.29 \pm 1.25$ & $18.79 \pm 1.04$ & -2.44 & $0.031^{*}$ \\
Male & $22.82 \pm 1.53$ & $21.84 \pm 1.26$ & -2.00 & 0.054 \\
\hline *p $<0.05$ & $\overline{\mathrm{x}}$ : mean & sd: standard deviation & & \\
\end{tabular}

Table IV. Female/Male national and amateur arm wrestlers' wrist circumference.

\begin{tabular}{lcccc} 
& National Arm Wrestlers & Amateur Arm Wrestlers & $\mathrm{t}$ & $\mathrm{p}$ \\
& $\overline{\mathrm{x}} \pm \mathrm{sd}$ & $\overline{\mathrm{x}} \pm \mathrm{sd}$ & & \\
\hline Female & $17.14 \pm 1.14$ & $15.29 \pm 1.58$ & -2.52 & $0.027^{*}$ \\
Male & $19.13 \pm 1.60$ & $18.22 \pm 2.06$ & -1.42 & 0.165 \\
\hline
\end{tabular}

*p<0.05 $\overline{\mathrm{x}}$ : mean sd: standard deviation

Table V. Female/Male national and amateur arm wrestlers' forearm circumference.

\begin{tabular}{lcccc}
\hline & $\begin{array}{c}\text { National Arm Wrestlers } \\
\overline{\mathrm{x}} \pm \mathrm{sd}\end{array}$ & $\begin{array}{c}\text { Amateur Arm Wrestlers } \\
\overline{\mathrm{x}} \pm \mathrm{sd}\end{array}$ & $\mathrm{t}$ & $\mathrm{p}$ \\
\hline Female & $26.57 \pm 2.37$ & $23.79 \pm 1.75$ & -2.50 & $0.028^{*}$ \\
Male & $31.73 \pm 2.58$ & $29.16 \pm 2.15$ & -3.10 & $0.004^{*}$ \\
\hline *p<0.05 & $\overline{\mathrm{x}}$ : mean & sd: standard deviation & &
\end{tabular}

\section{DISCUSSION}

The change in human elite athletic performance is determined by a complex interaction of socio-cultural, psychological, and close physiological factors (Brutsaert \& Parra). These characteristics of those with extraordinary abilities are associated with their genes to some extent.

Genetic predisposition plays a significant role in the development of physical athletic performance. It is also associated with several gene polymorphisms (Macarthur \& North). In this study, we examined rs 1805086 and rs1805065 polymorphisms of MSTN gene in national and amateur Turkish arm wrestlers and sedentary people, and we looked into the anthropometric properties such as hand circumference, wrist circumference, and forearm circumference of Turkish national and amateur arm wrestlers. Literature review on the subject showed that no studies had been done about rs 1805086 and rs1805065 polymorphisms on arm wrestling. Until today, studies on polymorphisms of MSTN gene have been carried out on the athletes of other fields such as swimmers, athletes, bodybuilders, and weightlifters. This study will contribute to the literature as the first study examining the rs1805086 and rs1805065 polymorphisms of the MSTN gene in arm wrestlers. In this study, 24 Turkish national (7 females, 17 males) arm wrestlers and 21 Turkish amateur ( 7 females, 14 males) arm wrestlers and 34 sedentary (12 females, 22 males) 
participants were investigated on. When the volunteers were examined in terms of rs 1805086 polymorphism of MSTN gene, it was found that KK genotype was found in the two groups with athletic backgrounds (100\%), and $94.12 \%$ of the sedentary group had KK genotype (Table I). In the other polymorphism of MSTN, rs 180506, only AA genotype (100 $\%$ ) was detected in all three groups (Table II). Kostek et al. (2009) examined the relationship between rs 1805086 polymorphism of MSTN and the force response to 12-week unilateral progressive strength training with a group of healthy adults in their study, and they found that the response to strength training was not related to the $153 \mathrm{R}$ polymorphism of MSTN (Kostek et al.). Their research showed similar results with our study. In this study, no rs1805086 polymorphism of MSTN was detected in any of the national and amateur Turkish arm wrestlers. However, in the sedentary group, two people with this polymorphism were found. This study revealed that the arm wrestlers were not affected by the strength gene, MSTN. Moreover, it was understood that other factors that might affect athletes' success should be investigated in further research. Ben-Zaken et al. (2015) in their study that they researched on shortlong distance athletes and short-long distance swimmers, investigated the prevalence of rs 1805086 polymorphism of MSTN in the elite athletes. Their first finding showed that allele and genotype frequencies did not differ between the athletes and sedentary participants in terms of age or gender.

Another finding is that the frequency of the MSTN 153R allele was higher among long-distance swimmers compared to short-distance swimmers. None of the longdistance swimmers carrying the MSTN 153RR genotype were elite athletes, and among the short-distance swimmers, there was only one athlete carrying the MSTN 153R allele. Ben-Zaken et al. emphasized that this polymorphism does not have a significant role in the success of swimmers, especially when sprinting. This result is consistent with our findings. Ferrell et al. in their research that they conducted with Caucasian and Afro-American females and males including body builders and elite athletes found out no significant effect of rs 1805086 and rs1805065 variants of MSTN on the strength training and muscle mass responses of the participants (Ferrell et al.). The research of Ferrell et $a l$. and Kostek et al., and this study showed parallel results. As a result of this study which investigated a strength sports, the arms wrestling, it was concluded that dominant genotype of rs1805086 variants of MSTN between the groups was mainly genotype KK.

Ivey et al. (2000), in their study with young/old females and males, found out that only five females out of thirty-two participants were carriers of myostatin gene variant. When MSTN genotypes evaluated for both genders, it was reported that there was no relationship between their responses to strength training and the rs1805086 polymorphism of MSTN, but the hypertrophic response was found only in female participants (Ivey et al.). Santiago et al. (2011) studied on 281 healthy young adult university students (214 males, 67 females); consequently, they emphasized that the variant 153R allele of the rs1805086 polymorphism of MSTN correlated with vertical jump performance in non-athletic young men but did not correlated with their sprint performance.

In our study, rs 1805086 polymorphism of MSTN was not observed in national and amateur Turkish arm wrestlers. As Santiago et al. stated, we cannot explain the category of athletes with this polymorphism. Filonzi et al. (2015) on their study with 16 females and 34 males 50 elite athletes who were native Caucasian, African-American, AfricanAmerican or New Zealanders, resulted that $153 \mathrm{KK}$ genotype was found to be mostly identified in both elite athletes and sedentary people respectively with $86 \%$ and $92 \%$.

Of all the subjects examined, 153RR genotype was found in only two subjects. It was also reported that these two subjects were from the sedentary group and that no athletes in the elite group had this genotype. Furthermore, heterozygous $153 \mathrm{KR}$ genotype was detected in $14 \%$ of elite athletes in $6 \%$ of controls. In this study which was conducted with arm wrestlers, the results showed a great similarity with the study of Filonzi et al. As a result of this study, it was found out that there was no direct relationship between rs1805086 polymorphism of MSTN and national and amateur athletes as the results of Filonzi et al. research suggested. Li et al. (2014) conducted a study with 94 sedentary males with Han Chinese ethnic origins whose ages ranged from 18 to 22 . Of the 94 subjects evaluated for rs 1805065 polymorphism of MSTN, it was stated that 81 of them ( 86.17 $\%)$ reported to have AA genotype, 12 of them $(12.17 \%)$ had AT genotype, and one of the participants (1.06\%) had TT genotype. In this study, a total of 94 participants evaluated for rs1805065 polymorphism of MSTN, and 88 of them $(93.62$ $\%)$ were found to have KK genotype, and the other 6 left (6.38 \%) had KR genotype, and nobody with RR genotype were observed. Therefore, it can be seen that the results of the rs1805065 polymorphism of MSTN evaluation for this study were similar with the results of Li et al. (2014). Moreover, these results on rs1805065 polymorphism of MSTN also largely overlapped with the results of Li et al. (2014).

There are many cognitive parameters that regulate several biological characteristics of successful athletes such as legs and arms, body shape, muscle strength, muscle metabolism and body. Genes play a significant role in 
determining these characteristics (Erog ${ }^{` l u}$ et al., 2018). In our study, although MSTN gene data across the groups concentrated on KK and AA polymorphisms, when anthropometric properties were evaluated, there were statistically significant differences between the groups (Tables III to V). These significant results showed similarities with the studies in the literature. Zileli et al. (2017) investigated the effects of wrist and hand circumference of female arm wrestlers on their performance during the competitions. The results showed that the hand circumference of athletes who were successful (those who were at the top three) in both left and right hand competitions was greater than the hand circumference of athletes (those who were not at the top three) who did not succeed in their competitions ( $\mathrm{p}<0.05)$.

Similarly, the wrist circumference values of the athletes who succeeded in the left and right hand competitions were greater than the wrist circumference of the unsuccessful athletes. However, no statistically significant difference was found on this issue ( $p>0.05$ ) (Zileli et al., 2017). In this study, on the contrary to the results of Zileli et al. (2017), there was a statistically significant difference between the hand circumference and the wrist circumference of the national and amateur Turkish arm wrestlers. Although there was not a statistically significant difference between men, hand and wrist circumference measurements were found to be greater in national athletes. These results were supported by the ideas in the studies of Sögüt et. al. (2004) and Shepieliev (2012).

Furthermore, Zileli et al. (2012) in their study conducted with arm wrestlers, found a positive correlation $(p<0.001)$ between the bicep muscle circumference, forearm circumference, humerus length, the hand circumference and hand width, and hand grip strength when they examined anthropometric characteristics of 53 male arm wrestlers competed in Turkey Intercollegiate Championship (Zileli et al., 2012). Akpinar et al. (2013) in their study they conducted with professional male arm wrestlers who were successful wrestlers (those who were at the top three) and unsuccessful wrestlers (those who were not at the top three) in European Championship National Team selection, compared the left and right forearm circumferences (69 right arm, 65 left arm) of the participating athletes. They found out that the athletes who succeeded using their left arm, had higher forearm circumferences ( $\mathrm{p}<0.5)$ (Akpinar et al.). In this study, when hand and wrist circumferences were evaluated in the group with males, the data from hand circumference did not show a statistically significant difference in national and amateur Turkish arm wrestlers; however, for both genders, forearm circumference was statistically significant between national and amateur Turkish arm wrestlers. Although the national athletes and amateur athletes were similar in terms of MSTN gene, they showed differences in terms of forearm circumference. The success of national athletes can be explained by forearm circumference values as Zileli et al. (2012) and Akpinar et al. demonstrate. Similar to the information in the literature (Zileli et al., 2012, 2017), it can be seen that athletes having greater anthropometric parameters are more likely to be successful in competitions.

Overall results of the study indicated that when rs1805086 region of the MSTN gene was investigated on, it was seen that all the groups with athletes $(100.0 \%)$ and 94.12 $\%$ of the sedentary participants had KK genotype, and when rs1805065 region was examined, we could see that all three groups (100.0\%) had AA genotype. Although both regions of the MSTN gene had some similarities, significant differences obtained by anthropometric parameters could be used to explain the success of athletes.

With the help of the study, that athletic performance is a multifactorial concept is proven again. For further studies, if the sample groups selected with a larger numbers of successful athletes (ranked at the top three) and participated in the World and European Championships, homozygous mutant genotypes may be more likely to be encountered with. Literature research has shown that there are limited studies in the field of arm wrestling. We believe that further studies will contribute a lot to this field.

USAÇ, G.; EROGLU, O. \& ZILELI, R. Evaluación de los polimorfismos rs 1805086 y rs 1805065 en el gen mstn y las propiedades antropométricas de los luchadores de brazo nacionales y amateurs. Int. J. Morphol., 38(4):1146-1152, 2020.

RESUMEN: El objetivo de este estudio fue investigar los polimorfismos rs 1805086 y rs1805065 del gen MSTN de luchadores de brazos turcos, nacionales y aficionados, y personas que llevan un estilo de vida sedentario, y las propiedades antropométricas además de las circunferencias de manos, muñecas y antebrazos de los luchadores de brazos turcos nacionales y aficionados. En este estudio, participaron un total de 79 voluntarios: 24 luchadores de brazos turcos nacionales ( 7 mujeres, 17 hombres), 21 luchadores de brazos turcos aficionados ( 7 mujeres, 14 hombres) y 34 personas sedentarias (12 mujeres, 22 hombres). Para analizar los datos, se utilizó el Paquete Estadístico para las Ciencias Sociales, SPSS 22 (SPSS Inc., Chicago, IL, EE. UU.). Como resultado del estudio, cuando se examinaron los datos sobre los polimorfismos rs1805086 y rs1805065 del gen MSTN respectivamente, se descubrió que el genotipo MSTN 153KK era 100,0 \% dominante en luchadores de brazos nacionales $(n=24)$ y aficionados $(n=21)$, y era $94,12 \%$ dominante en personas sedentarias. El genotipo KR se observó en el 5,88 \% de las personas sedentarias. Los datos del otro polimorfismo rs1805065 del gen MSTN mostraron que todos los participantes (n $=45 ; 100,0 \%$ ) eran portadores del genotipo homocigoto normal. Además, tanto para el grupo femenino como para el masculino, se encontró una diferencia estadísticamente significativa en términos de propiedades antropométricas. Se puede concluir que, aunque 
no hubo una diferencia significativa entre los luchadores de brazos turcos nacionales y aficionados en términos de sus características genéticas MSTN; en términos de propiedades antropométricas, se descubrieron diferencias significativas. Se descubrió que, en estos atletas, no fueron los polimorfismos del gen MSTN sino las propiedades antropométricas las efectivas.

PALABRAS CLAVE: Gen de miostatina; Lucha de brazos; Polimorfismo; Rendimiento deportivo; Circunferencia de la muñeca; Circunferencia de la mano; Circunferencia del antebrazo.

\section{REFERENCES}

Akpinar, S.; Zileli, R.; S, enyüzlü, E. \& Tunca, S. A. Anthropological and perceptual predictors affecting the ranking in arm wrestling competition. Int. J. Morphol., 31(3):832-8, 2013.

Amthor, H.; Huang, R.; McKinnell, I.; Christ, B.; Kambadur, R.; Sharma, M. $\&$ Patel, $\mathrm{K}$. The regulation and action of myostatin as a negative regulator of muscle development during avian embryogenesis. Dev. Biol., 251(2):241$57,2002$.

Anakwe, R. E.; Huntley, J. S. \& McEachan, J. E. Grip strength and forearm circumference in a healthy population. J. Hand Surg. Eur. Vol., 32(2):2039, 2007.

Ben-Zaken, S.; Meckel, Y.; Nemet, D.; Rabinovich, M.; Kassem, E. \& Eliakim, A. Frequency of the MSTN Lys $(\mathrm{K})-153 \mathrm{Arg}(\mathrm{R})$ polymorphism among track \& field athletes and swimmers. Growth Horm. IGF Res., 25(4):196-200, 2015.

Brown, L. E. Isokinetics in Human Performance. Champaign (Ill.), Human Kinetics, 2000.

Brutsaert, T. D. \& Parra, E. J. What makes a champion? Explaining variation in human athletic performance. Respir. Physiol. Neurobiol., 151(2-3):109-23, 2006.

Eroglu, O. \& Zileli, R. The effect of genetic factors on sportive performance. Int. J. Sport Exerc. Train. Sci., 1(1):63-76, 2015.

Eroglu, O.; Zileli, R.; Nalbant, M. A. \& Ulucan, K. Prevalence of alpha actinin3 gene (ACTN3) R577X and angiotensin converting enzyme (ACE) insertion / deletion gene polymorphisms in national and amateur Turkish athletes. Cell. Mol. Biol. (Noisy-le-grand), 64(5):24-8, 2018.

Ferrell, R. E.; Conte, V.; Lawrence, E. C.; Roth, S. M.; Hagberg, J. M. \& Hurley, B. F. Frequent sequence variation in the human myostatin (GDF8) gene as a marker for analysis of muscle-related phenotypes. Genomics, 62(2):2037, 1999.

Filonzi, L.; Franchini, N.; Vaghi, M.; Chiesa, S. \& Marzano, F. N. The potential role of myostatin and neurotransmission genes in elite sport performances. J. Biosci., 40(3):531-7, 2015.

GeneCards - The Human Gene Database. MSTN Gene (Protein Coding) Myostatin. Website, GeneCards - The Human Gene Database, 2018. Available from: https://www.genecards.org/cgi-bin/ carddisp.pl?gene=MSTN

Girgenrath, S.; Song, K. \& Whittemore, L. A. Loss of myostatin expression alters fiber-type distribution and expression of myosin heavy chain isoforms in slow- and fast-type skeletal muscle. Muscle Nerve, 31(1):34-40, 2005.

Grobet, L.; Martin, L. J.; Poncelet, D.; Pirottin, D.; Brouwers, B.; Riquet, J.; Schoeberlein, A.; Dunner, S.; Ménissier, F.; Massabanda, J.; et al. Adeletion in the bovine myostatin gene causes the double-muscled phenotype in cattle. Nat. Genet., 17(1):71-4, 1997.

Ivey, F. M.; Roth, S. M.; Ferrell, R. E.; Tracy, B. L.; Lemmer, J. T.; Hurlbut, D. E.; Martel, G. F.; Siegel, E. L.; Fozard, J. L.; Jeffrey Metter, E.; et al. Effects of age, gender, and myostatin genotype on the hypertrophic response to heavy resistance strength training. J. Gerontol. A Biol. Sci. Med. Sci., 55(11):M641-8, 2000.
Kostek, M. A.; Angelopoulos, T. J.; Clarkson, P. M.; Gordon, P. M.; Moyna, N. M.; Visich, P. S.; Zoeller, R. F.; Price, T. B.; Seip, R. L.; Thompson, P. D.; et al. Myostatin and follistatin polymorphisms interact with muscle phenotypes and ethnicity. Med. Sci. Sports Exerc., 41(5):1063-71, 2009.

Li, K.; Hewson, D. J.; Duchêne, J. \& Hogrel, J. Y. Predicting maximal grip strength using hand circumference. Man. Ther., 15(6):579-85, 2010.

Li, X.; Wang, S. J.; Tan, S. C.; Chew, P. L.; Liu, L.; Wang, L.; Wen, L. \& Ma, L. The A55T and K153R polymorphisms of MSTN gene are associated with the strength training-induced muscle hypertrophy among Han Chinese men. J. Sports Sci, 32(9):883-91, 2014.

Li, Z. B.; Kollias, H. D. \& Wagner, K. R. Myostatin directly regulates skeletal muscle fibrosis. J. Biol. Chem., 283(28):19371-8, 2008.

Lortie, G.; Bouchard, C.; Leblanc, C.; Tremblay, A.; Simoneau, J. A.; Thériault, G. \& Savoie, J. P. Familial similarity in aerobic power. Hum. Biol., 54(4):801-12, 1982.

Macarthur, D. G. \& North, K. N. Genes and human elite athletic performance. Hum. Genet., 116(5):331-9, 2005.

McPherron, A. C. \& Lee, S. J. Double muscling in cattle due to mutations in the myostatin gene. Proc. Natl. Acad. Sci. U. S. A., 94(23):12457-61, 1997.

McPherron, A. C.; Lawler, A. M. \& Lee, S. J. Regulation of skeletal muscle mass in mice by a new TGF-beta superfamily member. Nature, 387(6628):83-90, 1997.

Mosher, D. S.; Quignon, P.; Bustamante, C. D.; Sutter, N. B.; Mellersh, C. S.; Parker, H. G. \& Ostrander, E. A. A mutation in the myostatin gene increases muscle mass and enhances racing performance in heterozygote dogs. PLoS Genet., 3(5):e79, 2007.

Santiago, C.; Ruiz, J. R.; Rodríguez-Romo, G.; Fiuza-Luces, C.; Yvert, T.; Gonzalez-Freire, M.; Gómez-Gallego, F.; Morán, M. \& Lucia, A. The K153R polymorphism in the myostatin gene and muscle power phenotypes in young, non-athletic men. PLoS One, 6(1):e16323, 2011.

Schuelke, M.; Wagner, K. R.; Stolz, L. E.; Hübner, C.; Riebel, T.; Kömen, W.; Braun, T.; Tobin, J. F. \& Lee, S. J. Myostatin mutation associated with gross muscle hypertrophy in a child. N. Engl. J. Med., 350(26):2682-8, 2004.

Shepieliev, A. E. Anthropometric Features of Ukrainian National Women's team in Biathlone. $4^{\text {th }}$ International Conference Physical Activity and Sport at University, 2012. pp.150-3.

Sögüt, M.; Müniroglu, R. S. \& Deliceoglu, G. Investigation of anthropometric and somatotype characteristics of junior male tennis players in different Categories. Spormetre, 2(4):155-62, 2004.

Ulucan, K. Literature review of Turkish sportsmen in terms of ACTN3 R577X polymorphism. Clin. Exp. Health Sci., 6(1):44-7, 2016.

Ulucan, K. Need for sports genetics. J. Investig. Genom., 2(2):21, 2015.

Ulucan, K.; Bayyurt, G. M.; Konuk, M. \& Güney, A. I. Effect of alpha-actinin3 gene on trained and untrained Turkish middle-school children's sprinting performance: a pilot study. Biol. Rhythm Res., 45(4):509-14, 2013.

Zileli, R.; Diker, G. \& Özkamçi, H. The impact of wrist width and palm width to competition performance in professional female arm wrestlers. Sci. Mov. Health, 17(2 Suppl.):559-65, 2017.

Zileli, R.; Vatansever, Ö. S.; Özen, G. \& Ss enyüzlü, E. The correlation between strength and anthropometric charecteristics in arm wrestling athletes with performance. Online J. Recreat. Sport, 1(4):18-20, 2012.

\section{Corresponding author:}

Dr. Raif Zileli

Biotechnology Research and Applicaiton Centre

Bilecik Seyh Edebali University

Bilecik

TURKEY

E mail: raif.zileli@bilecik.edu.tr

Received: $20-12-2018$

Accepted: $16-03-2020$ 